Eur. J. Clin. Chem. Clin. Biochem.

Vol. 31, 1993, pp. 625-631

(C) 1993 Walter de Gruyter \& Co.

Berlin - New York

\title{
A Trypsin Sensitive Stromelysin Isolated from Rheumatoid Synovial Fluid is an Activator for Matrix Metalloproteinases
}

\author{
By H. Kolkenbrock ${ }^{1}$, Adelheid Hecker-Kia ${ }^{1}$, Dagmar Orgel ${ }^{1}$, G. Buchlow ${ }^{1}$, H. Sörensen ${ }^{2}$, W. Hauer ${ }^{2}$ and \\ N. Ulbrich ${ }^{1}$ \\ 1 Deutsches Rheuma-Forschungszentrum Berlin, AG Biochemie, Berlin, Germany \\ ${ }^{2}$ Immanuel-Krankenhaus GmbH, Rheumaklinik, Berlin, Germany
}

(Received April 16/June 21, 1993)

Summary: The processing of synovial fluids of patients suffering from rheumatoid arthritis led to the characterization of a neutral metalloproteinase with polymorphonuclear leukocyte progelatinase and polymorphonuclear leukocyte procollagenase activating properties. The activator exhibits a relative molecular mass of $M_{\mathrm{r}} 27000$ and is an active form of stromelysin. Thus, it reacts specifically with antibodies raised against human stromelysin, splits polymorphonuclear leukocyte progelatinase in a manner characteristic of stromelysin, and is inhibited by EDTA as well as by a tissue inhibitor of metalloproteinases (TIMP-2).

The activator shows a high specificity for the matrix metalloproteinases, polymorphonuclear leukocyte progelatinase and polymorphonuclear leukocyte procollagenase. It shows only weak hydrolysis of casein and gelatin, and it does not activate fibroblast $M_{\mathrm{r}} 72000$ progelatinase. Brief treatment with trypsin does not lead to a significant change in the activator's relative molecular mass, but induces a rapid loss of its activating activity for polymorphonuclear leukocyte progelatinase, while its proteolytic activity against the synthetic substrate, N-(2,4)-dinitrophenyl-Pro-Gln-Gly-Ile-Ala-Gly-Gln-D-Arg, is increased about 3-fold. The same tryptic treatment does not affect the activator's proteolytic activity towards casein and gelatin.

\section{Introduction}

Matrix metalloproteinases play an important role in remodelling of the extracellular matrix $(1,2)$. Since the structural elements of the extracellular matrix are all substrates, the activity of these enzymes must be strictly regulated. In certain diseases, e. g. rheumatoid arthritis, these control mechanisms do not function properly, leading to destruction of the extracellular matrix. In the special case of rheumatoid arthritis, destruction of the articular cartilage finally leads to the destruction of the whole joint.

\footnotetext{
1) Stromelysin EC 3.4.24.17

Polymorphonuclear leukocyte gelatinase EC 3.4.24.35

Fibroblast collagenase EC 3.4.24.7

Polymorphonuclear leukocyte collagenase EC 3.4.24.34

Trypsin EC 3.4.21.4

Plasmin EC 3.4.21.7
}

Matrix metalloproteinases are secreted as latent proenzymes by different cell types, such as fibroblasts, macrophages and polymorphonuclear leukocytes, in response to certain stimuli. An important regulatory mechanism involves activation of the latent enzymes in the extracellular space. In vitro metalloproteinases can be activated by organomercury compounds. Most matrix metalloproteinases are also activated by trypsin.

It is assumed that the physiological activator for the matrix metalloproteinases, collagenase ${ }^{1}$ ) and stromelysin ${ }^{1}$ ), might be plasmin ${ }^{1}$ ). Activated stromelysin (formerly called proteoglycanase) has a rather broad spectrum of activities; it hydrolyses not only proteoglycan, but also other components of the extracellular matrix, such as laminin, fibronectin, gelatins and collagen types III, IV, V and IX, and it is 
also reported to be a "superactivator" for plasminactivated collagenase, enhancing the collagenase activity about 10 -fold (3-5). Recently, it was reported that stromelysin is an activator for polymorphonuclear leukocyte progelatinase (6). Thus, stromelysin is not only an important proteinase with regard to its activity towards components of the extracellular matrix, but seems to play a key role in regulation of the activities of other matrix metalloproteinases.

Here we report some newly discovered properties of stromelysin (isolated from rheumatoid synovial fluid) that appear to extend the regulatory involvement of this enzyme.

\section{Materials and Methods}

\section{Materials}

Rheumatoid synovial fluid originated from patients of the Rheuma-Klinik, Immanuel-Krankenhaus, Berlin. Buffy coat was kindly supplied by Deutsches Rotes Kreuz, Berlin. Ultrogel AcA 44, blue-Trisacryl, heparin-Ultrogel and phorbol myristate acetate were purchased from Serva, Heidelberg. Gelatin-Sepharose was prepared in our laboratory. Sepharose 4-B was obtained from Pharmacia, Freiburg. 4-Aminophenylmercury acetate, plasmin $(3 \mathrm{U} / \mathrm{mg})$ and molecular mass markers for gel electrophoresis were obtained from Sigma. Protein concentrations were determined with the bicinchoninic acid reagent (Pierce, USA) with bovine albumin as standard.

\section{Enzyme assays}

Matrix metalloproteinase activities were assayed with the synthetic substrate $\mathrm{N}$-(2,4)-dinitrophenyl-Pro-Gln-Gly-Ile-AlaGly-Gln-D-Arg (dinitrophenyl-labelled peptide) (7). Activity against protein substrates, such as gelatin and casein was assayed by the fluorescamine method (8). Activator activity was analysed by incubating the activator with polymorphonuclear leukocyte progelatinase for $30 \mathrm{~min}$ at $37^{\circ} \mathrm{C}$ in the presence of the dinitrophenyl-labelled peptide. The amount of substrate hydrolysed by the activated polymorphonuclear leukocyte gelatinase was taken as a measure of activator concentration.

\section{Isolation of matrix metalloproteinases}

Polymorphonuclear leukocyte progelatinase and polymorphonuclear leukocyte procollagenase were purified from buffy coat after stimulation with phorbol-myristate acetate. The secreted metalloproteinases were purified essentially as described $(9,10)$. The $M_{\mathrm{r}} 72000$ progelatinase and the $M_{\mathrm{r}} 72000$ progelatinaseTIMP-2 complex were isolated according to 1. c. (11).

\section{Activator purification}

To $100 \mathrm{ml}$ of rheumatoid synovial fluid, saturated ammonium sulphate solution was added to $10 \%$ saturation. After $60 \mathrm{~min}$ in the cold the precipitate was removed by centrifugation at $40000 \mathrm{~g}$ for $30 \mathrm{~min}$, and the clear supernatant was adjusted to $50 \%$ ammonium sulphate saturation. After $24 \mathrm{~h}$ at $4{ }^{\circ} \mathrm{C}$ the precipitate was collected by centrifugation at $150000 \mathrm{~g}$ for 20 min, washed twice with $60 \mathrm{ml}$ ammonium sulphate solution $(313 \mathrm{~g} / \mathrm{l})$ and centrifuged again. The sediment was dissolved in $20 \mathrm{mmol} / \mathrm{l}$ imidazole-HCl, $\mathrm{pH} 6.1,0.5 \mathrm{~g} / \mathrm{l} \mathrm{Brij} 35,0.5 \mathrm{~g} / 1 \mathrm{NaN}_{3}$ and dialysed against $20 \mathrm{mmol} / 1$ imidazole- $\mathrm{HCl}, \mathrm{pH} 6.1$, $5 \mathrm{mmol} / 1 \mathrm{CaCl}_{2}, 0.5 \mathrm{~g} / 1 \mathrm{Brij} 35,0.5 \mathrm{~g} / 1 \mathrm{NaN}_{3}$ (buffer A) followed by dialysis against buffer $\mathrm{A}$. The sample was chromatographed on carboxymethyl-trisacryl $(5.5 \mathrm{~cm} \times 11 \mathrm{~cm})$ equilibrated in buffer $A$. After washing with buffer $A$, bound protein was eluted with buffer $A$ containing $0.5 \mathrm{~mol} / 1 \mathrm{NaCl}$ and stored at $-20^{\circ} \mathrm{C}$. After $300 \mathrm{ml}$ of synovial fluid had been processed the carboxymethyl-Trisacryl eluates were combined, dialysed against $50 \mathrm{mmol} / \mathrm{l}$ Tris- $\mathrm{HCl}, \mathrm{pH} 7.0,200 \mathrm{mmol} / \mathrm{l} \mathrm{NaCl}, 5 \mathrm{mmol} / \mathrm{l}$ $\mathrm{CaCl}_{2}, 1 \mu \mathrm{mol} / 1 \mathrm{ZnCl}_{2}, 0.5 \mathrm{~g} / 1 \mathrm{NaN}_{3}$ (buffer B) and chromatographed on gelatin-Sepharose $(4 \mathrm{~cm} \times 3 \mathrm{~cm})$ equilibrated in buffer B. Unbound protein was concentrated by ultrafiltration (Amicon, YM-10 membrane) and applied to Ultrogel AcA 44 $(3 \mathrm{~cm} \times 100 \mathrm{~cm})$ equilibrated in buffer $\mathrm{B}$. The activator-containing fractions were concentrated by ultrafiltration, dialysed against $20 \mathrm{mmol} / \mathrm{l}$ Tris- $\mathrm{HCl}, \mathrm{pH} 8.0 ; 5 \mathrm{mmol} / 1 \mathrm{CaCl}_{2}, 1 \mu \mathrm{mol} / \mathrm{l}$ $\mathrm{ZnCl}_{2}, 0.5 \mathrm{~g} / \mathrm{l} \mathrm{Brij} 35,0.5 \mathrm{~g} / 1 \mathrm{NaN}_{3}$ and applied to blueSepharose $(2.5 \mathrm{~cm} \times 7 \mathrm{~cm})$ equilibrated in the same buffer. The activator was slightly retarded on blue-Sepharose, and activator-containing fractions were concentrated by ultrafiltration, dialysed against buffer $\mathrm{A}$ and applied to heparin-Ultrogel (1.5 $\mathrm{cm} \times 8 \mathrm{~cm}$ ) equilibrated with buffer $A$. The activator did not bind to heparin-Ultrogel and was further purified by gel filtration on a calibrated AcA $44(2 \mathrm{~cm} \times 100 \mathrm{~cm})$ equilibrated in buffer B.

All following investigations of the matrix metalloproteinase activating properties of the activator were performed with polymorphonuclear leukocyte progelatinase.

\section{Demonstration of activator activity in SDS-PAGE}

The procedures employed are essentially those of Hibbs et al. (9). To determine the polymorphonuclear leukocyte progelatinase activating activity of the protein seen in polyacrylamide gel electrophoresis in the presence of sodium dodecyl sulphate (SDS-PAGE), $1 \mu \mathrm{g}$ activator was electrophoresed on a $12.5 \%$ gel. After electrophoresis, the gel was washed twice for $15 \mathrm{~min}$ in buffer $\mathrm{B}, \mathrm{pH} 7.6$, containing $25 \mathrm{~g} / \mathrm{l}$ Triton $\mathrm{X}-100$. After rinsing the gels briefly $(5 \mathrm{~min})$ in the above buffer without Triton X-100, the gel was sliced into $1 \mathrm{~mm}$ sections, and each slice was extracted with $200 \mu \mathrm{l}$ buffer B for 24 h at $4^{\circ} \mathrm{C} .90 \mu \mathrm{l}$ of each extract were mixed with $10 \mu \mathrm{l}(2 \mu \mathrm{g})$ polymorphonuclear leukocyte progelatinase and $100 \mu \mathrm{l}$ dinitrophenyl-labelled peptide and incubated at $37^{\circ} \mathrm{C}$. After $24 \mathrm{~h}$ the amount of hydrolysed substrate was determined.

To examine the gelatinase activity of the protein seen on SDSPAGE, $60 \mathrm{ng}$ activator were electrophoresed on a $10 \%$ SDSPAGE, containing $2 \mathrm{~g} / \mathrm{l}$ gelatin at $4{ }^{\circ} \mathrm{C}$. The gel was washed as described above and the zymogram was developed in $50 \mathrm{mmol} / \mathrm{l}$ Tris- $\mathrm{HCl}, 5 \mathrm{mmol} / 1 \mathrm{CaCl}_{2}, 1 \mu \mathrm{mol} / 1 \mathrm{ZnCl}_{2}, 10 \mathrm{~g} / \mathrm{l}$ Triton X-100, $0.2 \mathrm{~g} / \mathrm{l} \mathrm{NaN}, \mathrm{pH} 7.6$ for $24 \mathrm{~h}$ at $37^{\circ} \mathrm{C}$. The gels were stained with Coomassie brilliant blue.

\section{pH-Optimum}

Five $\mu \mathrm{l}(1 \mu \mathrm{g})$ polymorphonuclear leukocyte progelatinase were incubated with $5 \mu \mathrm{l}(15 \mathrm{ng})$ activator and $40 \mu \mathrm{l}$ buffer $B$ adjusted to $\mathrm{pH} 6.0,6.5,7.0,7.5,8.0,8.5$ and 9.0 . After $1 \mathrm{~h}$ at $37^{\circ} \mathrm{C}$, $50 \mu \mathrm{l}$ of a solution containing $200 \mathrm{mmol} / \mathrm{l}$ Tris- $\mathrm{HCl}$, pH 7.0; $200 \mathrm{mmol} / \mathrm{l} \mathrm{NaCl}, 5 \mathrm{mmol} / 1 \mathrm{CaCl}_{2}, 0.5 \mathrm{~g} / 1 \mathrm{NaN}_{3}$ and $100 \mu \mathrm{l}$ dinitrophenyl-labelled peptide were added. After an incubation of $30 \mathrm{~min}$ at $37^{\circ} \mathrm{C}$ the reaction was terminated and the amount of hydrolysed dinitrophenyl-labelled peptide was determined.

\section{Sensitivity to trypsin}

'Activator $(6 \mu \mathrm{g})$ in $198 \mu \mathrm{l}$ buffer B was incubated with $22 \mu \mathrm{l}$ bovine trypsin $(1 \mathrm{~g} / \mathrm{l})$ at $37^{\circ} \mathrm{C}$. Periodically $3.3 \mu \mathrm{l}$ were taken and added to $5 \mu \mathrm{l}$ aprotinin $(1 \mathrm{~g} / \mathrm{l})$ and $81.7 \mu \mathrm{l}$ buffer $\mathrm{B}$ to assay the activity against polymorphonuclear leukocyte progelatinase. To measure the activity against the dinitrophenyl-labelled pep- 
tide, $25 \mu$ l of the mixture were added to $5 \mu$ aprotinin and $70 \mu \mathrm{l}$ buffer B. The reaction was started with either $100 \mu$ dinitrophenyl-labelled peptide alone for $18 \mathrm{~h}$ (activity against dinitrophenyl-labelled peptide) or with the same substrate and additionally $10 \mu \mathrm{l}(2 \mu \mathrm{g})$ polymorphonuclear leukocyte progelatinase for $30 \mathrm{~min}$ (activator-activity).

\section{Sensitivity to plasmin}

The same procedure as described for the trypsin') sensitivity was applied to the investigation on the activator sensitivity towards plasmin $(1 \mathrm{~g} / \mathrm{l})$.

\section{Results}

\section{Activator purification}

The amount of activator that can be isolated from synovial rheumatoid fluid depends largely on the kind of treatment the patients received. Treatment with glucosteroids leads to a very low content or even a lack of metalloproteinases in the synovial fluid. Using only synovial fluid of patients without glucosteroid treatment we isolated usually $30-100 \mu \mathrm{g}$ activator from $100 \mathrm{ml}$ synovia.

Employing the method described, an activator for polymorphonuclear leukocyte progelatinase and polymorphonuclear leukocyte procollagenase with a mo-

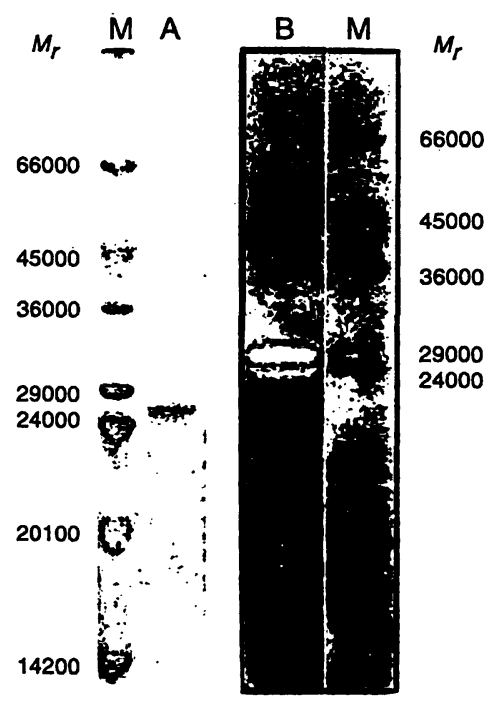

Fig. 1. Polyacrylamide gel electrophoresis in the presence of sodium dodecyl sulphate and zymogram of purified activator.

Lane A: $1 \mu \mathrm{g}$ activator on $12.5 \%$ polyacrylamide gel; electrophoresis in the presence of sodium dodecyl sulphate. Lane B: $60 \mathrm{ng}$ activator on $10 \%$ polyacrylamide; gel electrophoresis in the presence of sodium dodecyl sulphate containing $2 \mathrm{~g} / \mathrm{l}$ gelatin. Lane $\mathrm{M}$ : Molecular mass markers $\left(M_{\mathrm{r}}\right)$ : bovine albumin $(66000)$, ovalbumin (45000), glyceraldehyde-3-phosphate dehydrogenase $(36000)$, carbonic anhydrase $(29000)$, trypsinogen (24000), trypsin inhibitor (20100) and $\alpha$-lactalbumin (14200). lecular mass of $M_{\mathrm{r}} 27000$ was purified from human rheumatoid synovia. No activator could be detected in synovial fluid itself. The activator is detectable usually after Ultrogel AcA 44 chromatography, sometimes earlier, after gelatin-Sepharose chromatography. Up to this purification step, identification of the activator is based on its ability to hydrolyse the dinitrophenyl-labelled peptide.

The relative molecular mass of the activator was determined in different ways: on a calibrated Ultrogel AcA 44 column the activator was eluted in the range $M_{\mathrm{r}} 26000-28000$, in $12.5 \%$ polyacrylamide gel electrophoresis in the presence of sodium dodecyl sulphate a main band at $M_{\mathrm{r}} 27000$ with one or two minor bands with lower relative molecular masses could be visualized and a gelatin-zymogram showed proteolytic activity at the same position (fig. 1). When larger quantities of activator were applied, an additional band at $M_{\mathrm{r}} 25000$ was observed on the zymogram. Assay of activator in eluates of sliced $12.5 \%$ SDS-polyacrylamide gels showed activator activity associated with the region corresponding to $M_{\mathrm{r}}$ $26000-28000$.

Activity towards polymorphonuclear leukocyte procollagenase and fibroblast $M_{\mathrm{r}} 72000$ progelatinase

The activator quickly activated polymorphonuclear leukocyte procollagenase, as already described (1315). Fibroblast $M_{\mathrm{r}} 72000$ progelatinase was not activated.

\section{pH-Optimum}

The activator shows a $\mathrm{pH}$-optimum between $\mathrm{pH} 7.0$ and 8.0 (data not shown).

\section{Inhibition of the activator}

The activator was inhibited by EDTA and the activity could not be restored by dialysing against buffer B. It was also inhibited by a slight excess of the $M_{\mathrm{r}}$. 72000 progelatinase-TIMP-2 complex (fig. 2), which acts in the same manner as TIMP-2 (11).

\section{Trypsin-sensitivity}

The activator displayed a pronounced sensitivity to trypsin; after $30 \mathrm{~min}$ incubation at $37^{\circ} \mathrm{C}$ more than $80 \%$ of the activator-activity was lost. In contrast, under identical conditions, a $30 \mathrm{~min}$ incubation resulted in a threefold enhancement of the hydrolysis of the dinitrophenyl-labelled peptide (fig. 3). Treat- 


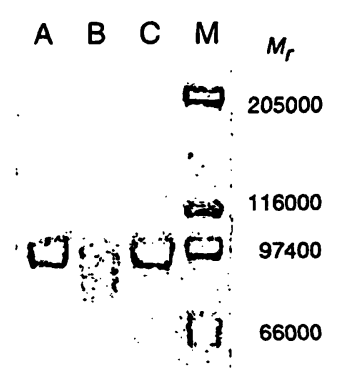

(4) 45000

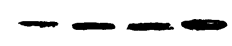

Fig. 2. $8 \%$ Polyacrylamide gel electrophoresis in the presence of sodium dodecyl sulphate. Inhibition of activator by EDTA and by fibroblast $M_{\mathrm{r}} 72000$ progelatinase-TIMP2-complex.

$2 \mu \mathrm{g}$ polymorphonuclear leukocyte progelatinase in $10 \mu \mathrm{l}$ buffer B were incubated for $45 \mathrm{~min}$ at $37^{\circ} \mathrm{C}$ with $150 \mathrm{ng}$ activator in $5 \mu \mathrm{l}$ buffer $\mathrm{B}$ preincubated for $5 \mathrm{~min}$ at $37^{\circ} \mathrm{C}$ with (Lane A) $800 \mathrm{ng} M_{\mathrm{r}} 72000$ progelatinaseTIMP-2 complex in $20 \mu \mathrm{l}$ buffer B, (Lane B) $20 \mu \mathrm{l}$ buffer $\mathrm{B}$, and (Lane C) $20 \mu \mathrm{l}$ of $100 \mathrm{mmol} / \mathrm{l} \mathrm{Tris} / \mathrm{HCl}, 50$ $\mathrm{mmol} / \mathrm{l} \mathrm{EDTA,} 200 \mathrm{mmol} / \mathrm{l} \mathrm{NaCl} 0.5 \mathrm{~g} / 1 \mathrm{NaN}_{3}, \mathrm{pH} 7.0$. (Lane $\mathrm{M})$. Molecular mass markers $\left(M_{\mathrm{r}}\right)$ : myosin (205000), $\beta$-galactosidase (116000), phosphorylase b $(97400)$, bovine albumin (66000) and ovalbumin (45000).

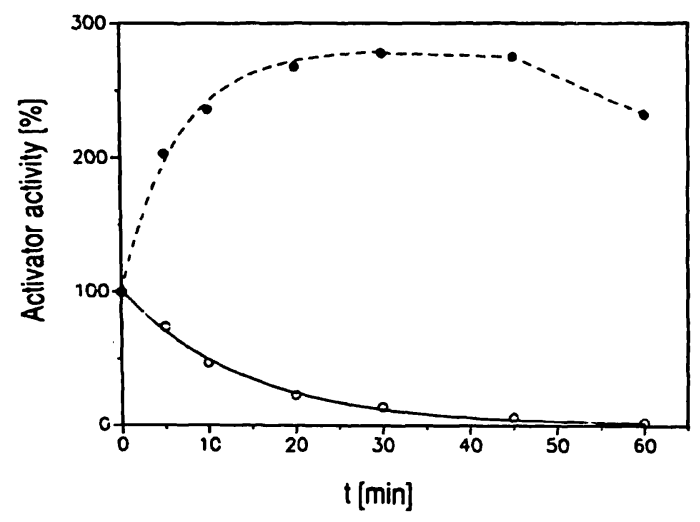

Fig. 3. Trypsin-sensitivity of the activator activity. $6 \mu \mathrm{g}$ activator in $200 \mu \mathrm{l}$ buffer B were incubated with $22 \mu \mathrm{g}$ trypsin in $22 \mu \mathrm{l} 1 \mathrm{mmol} / 1 \mathrm{HCl}$ at $37^{\circ} \mathrm{C}$. At the indicated times aliquots were withdrawn and activator activity towards polymorphonuclear leukocyte progelatinase (open circles) and dinitrophenyl-labelled peptide (solid circles) was determined.

ment with trypsin for $25 \mathrm{~min}$ at $37^{\circ} \mathrm{C}$ did not alter the proteolytic activity of the activator against casein and gelatin (fig. 4). The action of trypsin reduced the molecular mass of the activator by $M_{\mathrm{r}} 1000-2000$, as shown by Western-blot analysis (fig. 5). Prolonged incubation with trypsin led to the destruction of the activator.

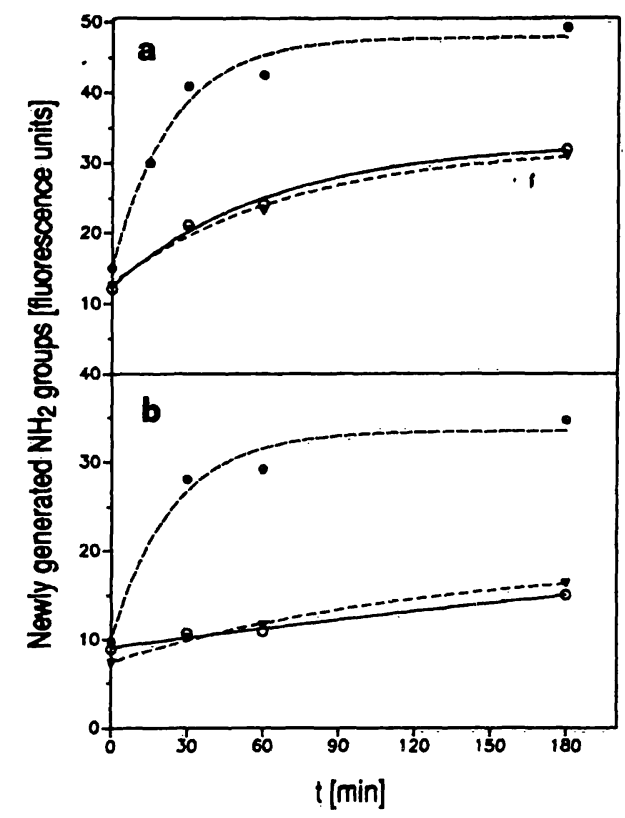

Fig. 4. Hydrolysis of casein (a) and gelatin (b) by the activator, trypsin-treated activator and by trypsin.

$100 \mu \mathrm{g}$ gelatin or casein, respectively, were incubated in a total volume of $200 \mu \mathrm{l}$ buffer B with $1.2 \mu \mathrm{g}$ activator (open circles), $1.2 \mu \mathrm{g}$ activator preincubated with trypsin at $37^{\circ} \mathrm{C}$ (solid triangles) or with $1.3 \mu \mathrm{g}$ trypsin (solid circles). At the indicated times newly generated amino groups were determined with the fluorescamine method. The tryptic treatment of the activator was stopped with $6 \mu \mathrm{g}$ aprotinin after $25 \mathrm{~min}$.

\section{Plasmin-sensitivity}

Under the conditions employed plasmin had no effect on the activator (data not shown). Even an incubation of $15 \mathrm{~h}$ at $37^{\circ} \mathrm{C}$ did not change the activator's activity towards polymorphonuclear leukocyte gelatinase or the dinitrophenyl-labelled peptide.

\section{Activation of polymorphonuclear leukocyte gelatinase}

The treatment of polymorphonuclear leukocyte progelatinase with the activator led via an $M_{\mathrm{r}} 86000$ intermediate to an active gelatinase with a molecular mass of $M_{\mathrm{r}} 82000$, (fig. 6) exactly as described for the action of stromelysin on polymorphonuclear leukocyte progelatinase (6).

\section{Substrate specificity}

The specific activity of the activator against the dinitrophenyl-labelled peptide was $40 \mathrm{mU} / \mathrm{mg}$, which is about $4 \%$ of polymorphonuclear leukocyte gelatinase activity against that substrate (11). It can be deduced from figure 4 that the activator's activity against casein is about 3 times higher than against gelatin. Compared with trypsin, however, the activator's activity towards these substrates is rather low, i.e. less than $10 \%$ of the trypsin activity towards gelatin and 


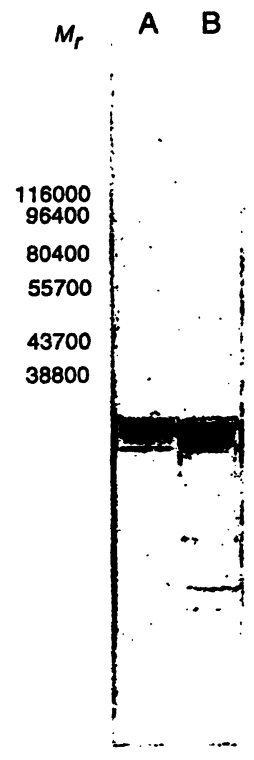

Fig. 5. Immunoblotting of activator and of trypsin treated activator.

$600 \mathrm{ng}$ activator in $20 \mu \mathrm{l}$ buffer B (Lane A) and $600 \mathrm{ng}$ activator in $20 \mu \mathrm{l}$ buffer B incubated with $2 \mu \mathrm{g}$ trypsin in $2 \mu 11 \mathrm{mmol} / 1 \mathrm{HCl}$ at $37^{\circ} \mathrm{C}$ for $30 \mathrm{~min}$ (Lane B) were run on a $12.5 \%$ polyacrylamide gel in the presence of sodium dodecyl sulphate, blotted on a Millipore Immobilon membrane and blocked overnight with bovine serum albumin. The blots were incubated with an antiserum raised in sheep against human stromelysin, followed by peroxidase-labelled anti-sheep-IgG. The reactive bands were visualized with 4-chloro-1-naphthol. The tryptic treatment was stopped with $2 \mu \mathrm{g}$ aprotinin in $2 \mu \mathrm{l}$ distilled water. The position of the apparent molecular mass for prestained protein is indicated: $\beta$ galactosidase (116000), fructose-6-phosphate kinase (96400), pyruvate kinase (80400), ovalbumin (55 700), lactic dehydrogenase (43700) and triosephosphate isomerase $(38800)$.

about $20 \%$ of that towards casein. Trypsin and activator are compared with respect to their polymorphonuclear leukocyte progelatinase activating properties in table 1 , where it can be seen that the relationship is reversed, i.e. the activator is nearly 30 times more efficient than trypsin in the activation of polymorphonuclear leukocyte progelatinase.

Tab. 1. Activation of polymorphonuclear leukocyte progelatinase by activator and trypsin

$2 \mu \mathrm{g}$ polymorphonuclear leukocyte progelatinase in 100 $\mu l$ buffer $B$ and varying amounts of activator displaying a molecular mass of $M_{r} 27000$ or bovine trypsin displaying molecular mass of $M_{\mathrm{r}} 24000$, respectively, were mixed with $50 \mu \mathrm{g}$ dinitrophenyl-labelled peptide in 100 $\mu l$ buffer $B$ and incubated for $30 \mathrm{~min}$ at $37^{\circ} \mathrm{C}$.

\begin{tabular}{lccc}
\hline Activator & $\begin{array}{l}\text { Substrate } \\
\text { hydrolysed } \\
(\mathrm{nmol})\end{array}$ & $\begin{array}{l}\text { Trypsin } \\
(\mathrm{ng} / 200 \mu \mathrm{l})\end{array}$ & $\begin{array}{l}\text { Substrate } \\
\text { hydrolysed } \\
(\mathrm{nmol})\end{array}$ \\
\hline 0 & 0 & 0 & 0 \\
30 & 3.8 & 600 & 2.5 \\
45 & 5.5 & 1200 & 5.2 \\
60 & 7.8 & 1800 & 7.9 \\
75 & 9.9 & 2400 & 11.2 \\
90 & 12 & - & - \\
\hline
\end{tabular}

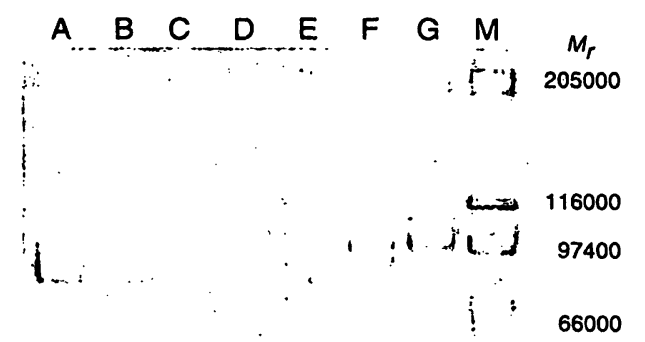

45000

Fig. 6. Activation of polymorphonuclear leukocyte progelatinase with activator.

$1 \mu \mathrm{g}$ polymorphonuclear leukocyte progelatinase in $5 \mu \mathrm{l}$ buffer $B$ was incubated with $30 \mathrm{ng}$ activator in $1 \mu \mathrm{l}$ buffer B for 60 (Lane A), 45 (Lane B), 30 (Lane C), 20 (Lane D), 10 (Lane E), 5 (Lane F) and 0 (Lane G) min, respectively, and analysed on $8 \%$ polyacrylamide gel electrophoresis in the presence of sodium dodecyl sulphate. Lane $\mathrm{M}$ : molecular mass markers $\left(M_{\mathrm{r}}\right)$ : myosin (205000), $\beta$-galactosidase (116000), phosphorylase 97400), bovine albumin (66000) and ovalbumin (45000)

\section{Discussion}

From the synovial fluid of patients suffering from rheumatoid arthritis, we isolated an activator for polymorphonuclear leukocyte procollagenase and polymorphonuclear leukocyte progelatinase, with a relative molecular mass of $M_{\mathrm{r}} 27000$. Furthermore, we demonstrated that the activator is an active form of the matrix metalloproteinase stromelysin; the activator is inhibited by EDTA and the $M_{\mathrm{r}} 72000$ gelatinase-TIMP-2 complex, which acts as an inhibitor for matrix metalloproteinases the same way as TIMP (11), thereby establishing that the activator is a member of the family of matrix metalloproteinases. The activator reacts with antibodies raised against human stromelysin, its $\mathrm{pH}$-optimum lies in the neutral range, and it splits the polymorphonuclear leukocyte gelatinase in a manner characteristic of stromelysin.

The activator was not only found in synovia of patients suffering from rheumatoid arthritis but also in the synovia of patients with osteoarthritis or systemic lupus erythematosus during an inflammatory attack. The activator could not be detected in synovia from non-inflammatory joints, e.g. distorsion of the knee.

Synovia subsequently found to contain a high concentration of activator also displayed a general enhancement of matrix metalloproteinase activity. Activator activity was not detectable in synovial fluids but became apparent after the chromatographic step 
on Ultrogel AcA 44, sometimes earlier, after gelatinSepharose. Latent prostromelyin is therefore activated during the purification procedure. Whether this is due to the action of other proteinases or to an autocatalytic process is still unclear.

We believe that an activator for polymorphonuclear leukocyte collagenase and polymorphonuclear leukocyte gelatinase that was isolated from synovial fluid $(12-14)$ and from the culture media of synoviocytes (15) many years ago is also stromelysin. However, this activator had a reported relative molecular mass of $M_{\mathrm{r}} 35000$ and it lacked proteolytic activity against casein and gelatin. We could not detect activator activity in the relative molecular mass range of $M_{\mathrm{r}}$ 35000 , either on a calibrated Ultrogel AcA 44, or by eluting protein from sliced SDS-polyacrylamide electrophoresis gels.

Polymorphonuclear leukocyte progelatinase, polymorphonuclear leukocyte procollagenase, fibroblast $M_{\mathrm{r}} 72000$ progelatinase, casein, gelatin and dinitrophenyl-labelled peptide were examined as substrates for the proteolytic activity of the activator. With the exception of the fibroblast $M_{\mathrm{r}} 72000$ progelatinase, the activator hydrolysed all these substrates, but showed a rather high degree of specificity for polymorphonuclear leukocyte progelatinase and polymorphonuclear leukocyte procollagenase. The activator was much less active than trypsin in the proteolysis of casein and gelatin. However, although trypsin is a potent activator for polymorphonuclear leukocyte progelatinase (16), the stromelysin activator is about 30 times more efficient. The activator displays a similar efficiency in the activation of polymorphonuclear leukocyte collagenase, while the fibroblast $M_{\mathrm{r}} 72000$ progelatinase is not a substrate for the activator. The high specificity for the matrix metalloproteinases displayed by neutrophilic granulocytes may indicate a physiological role of this activator in the activation of these proteinases. This specificity may also explain why the $M_{\mathrm{r}} 35000$ activator described earlier was not found to hydrolyse gelatin and casein; activator concentrations too low to significantly hydrolyse gelatin and casein are still sufficient to rapidly activate the polymorphonuclear leukocyte progelatinase.

Hydrolysis of the dinitrophenyl-labelled peptide by the activator was slow compared with the rate of hydrolysis by polymorphonuclear leukocyte gelatinase. However, a short tryptic treatment, that did not lead to a significant change in the molecular mass of the activator (fig. 5), enhanced the activator's activity against the dinitrophenyl-labelled peptide about threefold, destroyed its ability to activate polymorphonuclear leukocyte progelatinase and did not affect its activity against casein and gelatin. It might therefore be concluded that a similar physiological proteolytic event may significantly increase the activator's activity against some components of the extracellular matrix. Plasmin, a proteinase with proteolytic properties similar to trypsin, plays an important role under physiological conditions in the activation of procollagenase (MMP-1) and prostromelysin, but it had no effect on the activator.

It could be argued that the three different trypsin sensitivities of the activator might be due to the presence of two different proteinases that react with trypsin in different ways:

1. the activator (active stromelysin) which hydrolyses the dinitrophenyl labelled peptide, casein/gelatin and the polymorphonuclear leukocyte progelatinase, and which is inactivated by trypsin;

2. a latent metalloproteinase which, after activation by trypsin, could be responsible for the enhanced turnover of the dinitrophenyl labelled peptide, and which at the same time compensates the loss of the caseinolytic/gelatinolytic activity of the activator. According to the relative molecular mass this metalloproteinase could only be matrilysin (MMP-7), but so far this enzyme has only been found in the uterus (17) and in developing macrophages (18). In addition, in synovial fluid, no such small latent metalloproteinase could be detected after chromatography on Ultrogel AcA 44 (not shown).

The distinct sensitivity to trypsin of the activator's proteolytic activity towards different substrates suggests that during the transformation from prostromelysin to active stromelysin at least one switch position is passed. At this switch position a putative regulatory mechanism may have the option of quickly deciding whether stromelysin should function as an activator for matrix metalloproteinases, or concomitantly, with enhanced activity, as a proteinase of other substrates.

Recently, it was reported that treatment of prostromelysin with $p$-aminophenylmercury acetate led to the formation of an activator for polymorphonuclear leukocyte progelatinase with a relative molecular mass of $M_{\mathrm{r}} 47000$ (6). This activator was not investigated with regard to its sensitivity to trypsin and it would be interesting to know if this $M_{\mathrm{r}} 47000$ activator behaves in the same way as the $M_{\mathrm{r}} 27000$ activator described in the present report.

The activity of matrix metalloproteinases in the extracellular space is subject to regulation on at least three different levels - expression, activation, and interaction with specific inhibitors. The present data 
extend this regulatory repertoire by the observation that stromelysin may be further processed to active species displaying distinct and separate functions as activators or hydrolytic enzymes of macromolecules of the extracellular matrix.

We are now investigating whether a mechanism is present in the synovial fluid of patients afflicted by

\section{References}

1. Matrisian, L. M. (1992) The matrix-degrading metalloproteinases. BioEssays 14, 455-463.

2. Birkedal-Hansen, H., Werb, Z., Welgus, H. \& Van Wart, H. (eds.) (1992) Matrix Metalloproteinases and Inhibitors Gustav Fischer, Stuttgart, Jena, New York.

3. Murphy, G., Cockett, M. I., Stephens, P. E., Smith, B. J. \& Docherty, A. J. P. (1987) Stromelysin is an activator of procollagenase. A study with natural and recombinant enzymes. Biochem. J. 248, 265-268.

4. Ito, A. \& Nagase, H. (1988) Evidence that human rheumatoid synovial matrix metalloproteinase 3 is an endogenous activator of procollagenase. Arch. Biochem. Biophys. $267,211-216$.

5. He, Ch., Wilhelm, S. M., Pentland, A. P., Marmer, B. L., Grant, G. A., Eisen, A. Z. \& Goldberg, G. J. (1989) Tissue cooperation in a proteoolytic cascade activating human interstitial collagenase. Proc. Natl. Acad. Sci. USA 86, $2632-2636$.

6. Ogata, Y., Enghild, J. J. \& Nagase, H. (1992) Matrix metalloproteinase 3 (stromelysin) activates the precursor of the human matrix metalloproteinase 9. J. Biol. Chem. 267, $3581-3584$.

7. Masui, Y., Takemoto, T., Sakakibara, S. \& Hori, H. (1977) Synthetic substrates for vertebrate collagenase. Biochem. Med. 17, 215-221.

8. Macartney, H. W. \& Tschesche, H. (1980) Latent collagenase from human polymorphonuclear leukocytes and activation to collagenase by removal of an inhibitor. FEBS Lett. 119, 327-332.

9. Hibbs, M. S., Hasty, K. A., Seyer, J. M., Kang, A. H. \& Mainardi, C. L. (1985) Biochemical and immunological characterization of the secreted forms of human neutrophil gelatinase. J. Biol. Chem. 260, 2493-2500.

10. Hasty, K. A., Hibbs, M. S., Kang, A. H. \& Mainardi, C. L. (1986) Secreted forms of human neutrophil collagenase. J. Biol. Chem. 261, 5645-5650. rheumatoid arthritis, which under physiological conditions may initiate a cascade of events, producing and processing stromelysin as described here in vitro.

\section{Acknowledgement}

This work was supported by Hoechst AG, Frankfurt am Main, Germany.

11. Kolkenbrock, H., Orgel, D., Hecker-Kia, A., Noack, W. \& Ulbrich, N. (1991) The complex between a tissue inhibitor of metalloproteinases (TIMP-2) and 72-kDa progelatinase is a metalloproteinase inhibitor. Eur. J. Biochem. 198, 775781.

12. Kruze, D. \& Wojtecka, E. (1972) Activation of leucocyte collagenase proenzyme by rheumatoid synovial fluid. Biochim. Biophys. Acta 285, 436-446.

13. Wize, J., Sopata, I., Wojtecka-Lukasik, E., Ksiezny, S. \& Dancewicz, A. M. (1975) Isolation, purification and properties of a factor from rheumatoid synovial fluid activating the latent forms of collagenolytic enzymes. Acta Biochimica Polonica 22, 239-250.

14. Dancewicz, A. M., Wize, J., Sopata, I., Wojtecka-Lukasik, E. \& Ksiezny, S. (1978) Specific and nonspecific activation of latent collagenolytic proteases of human polymorphonuclear leukocytes. In: Neutral Proteases of Human Polymorphonuclear Leukocytes (Havemann, K. \& Janoff, A., eds.) pp. 373-383, Urban \& Schwarzenberg, Inc. Baltimore-Munich.

15. Wize, J., Abgarowicz, T., Wojtecka-Lukasik, E., Ksiezny, S. \& Dancewicz, A. M. (1975) Activation of human leucocyte procollagenase by rheumatoid synovial tissue culture medium. Ann. Rheum. Dis. 34, 520-523.

16. Kolkenbrock, H., M.-Ali, H., Hecker-Kia, A., Buchlow, G., Sörensen, H., Hauer, R. W. \& Ulbrich, N. (1991) Characterization of a Gelatinase from Human Rheumatoid Synovial Fluid Cells. Eur. J. Clin. Chem. Clin. Biochem. 29, 499-505.

17. Woessner, J. F. jr. \& Taplin, C. J. (1988) Purification and properties of a small latent matrix metalloproteinase of the rat uterus. J. Biol. Chem. 263, 16918-16925.

18. Busiek, D. F., Ross, F. P., McDonnell, S., Murphy, G., Matrisian, L. M. \& Welgus, H. G. (1992) The matrix metalloproteinase matrilysin (PUMP) is expressed in developing human mononuclear phagocytes. J. Biol. Chem. $267,9087-9092$.

Dr. Hansjörg Kolkenbrock

Deutsches Rheumaforschungszentrum Berlin

Ostpreußendamm 111

D-12207 Berlin

Gẹmany 


\section{、}

